\title{
Service Learning Integration in an ABET-CAC Accredited Program Information Systems Curriculum
}

\author{
Frederick G. Kohun \\ Robert Morris University, \\ Pittsburgh, Pennsylvania, USA \\ kohun@rmu.edu
}

\author{
Gary J. DeLorenzo \\ California University of \\ Pennsylvania, California, \\ Pennsylvania, USA \\ delorenzo@calu.edu
}

\section{Azad I. Ali \\ Indiana University of Pennsylvania, Indiana, Pennsylvania, USA azad.ali@iup.edu}

\begin{abstract}
This paper provides a framework to integrate service learning threads into an ABET-CAC accredited curriculum based on the IS 2002 Model IS Curriculum. Examples from segments of successful IS service learning curricular adaptations are given in the context of a blueprint for integration into an ABET-CAC accreditable IS Curriculum. Additionally, a solution to the problem for institutional validation and certification of a service learning experience akin to the academic transcript is proposed.
\end{abstract}

Keywords: Service learning, technology service projects, computer information systems accreditation, ABET-CAC accreditation, IS model curriculum

\section{Introduction}

Since 1997 there has been an active professional movement to standardize and accredit information systems education in higher education. The focus had been initially on the development, dissemination, acceptance, and implementation of IS model curricula. ACM and AITP had been behind much of the curricular work. The leaders of the model curriculum standardization initiative including John T. Gorgone, Gordon B. Davis, Joseph S. Valacich, Heikki Topi, David L. Feinstein, and Herbert E. Longenecker, Jr. (to name a few) envisioned an accreditation for IS programs parallel to AACSB for business programs and ABET for engineering programs. This vi-

Material published as part of this publication, either on-line or in print, is copyrighted by the Informing Science Institute. Permission to make digital or paper copy of part or all of these works for personal or classroom use is granted without fee provided that the copies are not made or distributed for profit or commercial advantage AND that copies 1) bear this notice in full and 2) give the full citation on the first page. It is permissible to abstract these works so long as credit is given. To copy in all other cases or to republish or to post on a server or to redistribute to lists requires specific permission and payment of a fee. Contact 0HPublisher@InformingScience.org to request redistribution permission. sion was realized in 2002 with finalization of an IS accrediting body through a re-organized ABET to include the Computing Accreditation Commission (CAC). The CAC provided accreditation oversight to computer science and information systems programs under the overall direction of the Computer Science Accreditation Board (CSAB). The criteria that became the basis of the accreditation standards evolved from the 
existing model curricula. Included in those standards was an emphasis on general knowledge, technical skill in both fundamental and advanced information systems topics, and a professional focus. In other words, both theory and practice. While it is common to integrate "real world" projects and internships as part of the IS curricular pedagogy, this paper provides an alternative that supersedes what is typically done. Service learning is introduced as a vehicle to provide practical and professional application of the theory presented in the classroom. This serves two purposes - an internship like experience integrated with the fundamental and advanced courses offered as part of the curriculum, and true integration of an ABET criteria focusing, in part, on the social impact of information systems in a global economic environment. The paper will discuss service learning, the IS 2002 curriculum as a compatible environment for service learning and information systems education integration, compatibility within the ABET-CAC accrediting criteria, and finally how this IS-service learning integration can be validated and institutionally certified.

\section{Service Learning}

Individuals Service learning is both a method of teaching and a way of learning that integrates community service with instruction designed to promote civic responsibly (Battistoni, 2002). Within this learning environment, educators facilitate students' engagement in problem-solving activities comprised of sensory awareness, emotions, physical conditions, and cognition (Carver, 1997). This theory builds on Dewey's concept of situational learning where learning is the result of interactions between the individual and the environment. The service experience provides both a process of acquiring new knowledge through refection, and an opportunity for further inquiry within the context of a given situation (Giles \& Eyler, 1994).

Stanton, Giles, and Cruz (1999) indicated that service learning is an effective model for creating and studying a highly authentic learning environment, where instruction emphasizes the idea that much of what is learned is specific to the situations in which it is learned (Sweeney \& Paradis, 2004). These experiences include activities that are participatory, interactive, and representative of real-world events (Wenger, McDermott, \& Snyder, 2002). From an instructional perspective, learning is anchored in real contexts, where problem solving, critical thinking, and reflection are required (Howard, 1998).

Social interactions, which play a fundamental role in service learning activities, allow students to engage in debate, ask questions, state opinions, negotiate meanings, and resolve conflicts. All of these behaviors are believed to lead to reflection and internalization of new understandings (Brown, Metz, \& Campione 1996). In many ways, this is similar to Vygotsky's (1978) theory of social learning, which assumes that cognitive development occurs twice: first, between people (interpsychological) and then inside the individual (intrapsychological). A second aspect of Vygotsky's theory is the idea that the potential for cognitive development depends upon the "zone of proximal development" (ZPD): a level of development attained when people engage in social behavior. This theory assumes that skills developed with guidance or peer collaboration exceed what can be attained alone.

Peer feedback in service learning activities occurs when students observe each other testing, challenging, and revising ways of thinking about a particular problem. This iterative method of learning is critical to the formation of a collective knowledge base from which students are able gain deeper understandings of the thinking processes of the community. Social learning theory emphasizes the importance of observing and modeling the behaviors, attitudes, and emotional reactions of others (Brown \& Palincsar, 1989; Jonassen \& Henning, 1999). Bandura (1977) stated:

Learning would be exceedingly laborious, not to mention hazardous, if people had to rely solely on the effects of their own actions to inform them of what to do. Fortunately, most 
human behavior is learned observationally through modeling: from observing others one forms an idea of how new behaviors are performed, and on later occasions this coded information serves as a guide for action (p. 22).

\section{How Service Learning Differs From Traditional Classroom Experiences}

According to Weigert (1998), six elements differentiate and characterize service learning from traditional classroom experiences. Three of these elements focus on instruction: (1) the service flows from and into course objectives; (2) assignments requiring reflection integrate the service with course objectives; and (3) the assignment is assessed and evaluated. The other three elements focus on the community: (1) the service is meaningful to the community; (2) the service meets a need or goal; and (3) the community defines the need or goal.

McPherson (1996) identified the critical components for developing service learning activities that address all six of these elements:

- Service-learning activities maximize student participation in selecting, designing, implementing, and evaluating the service project.

- Service-learning activities value diversity in participants, practice, and outcomes.

- Service-learning activities promote communication and interaction with the community and encourage partnerships and collaboration.

- Students prepare for all aspects of their service work, including a clear understanding of the task, the skills and information required to complete the task, awareness of safety precautions, and knowledge about and sensitivity to colleagues.

- Student reflection takes place before, during, and after service; uses multiple methods to encourage critical thinking; and is central in the design and fulfillment of curricular objectives.

- Multiple methods are designed to acknowledge, celebrate, and validate student service work.

Essential for quality service learning instruction is the development of clear educational goals that require students to construct their own knowledge and understandings about a given problem. Lesh (2002) explained that to learn about the nature of students' developing knowledge, it is useful to focus on tasks in which the resulting products demonstrate significant information about the ways of thinking that produced them. This means that students need to be able to communicate how they interpreted a task or problem-solving situation. Within a service learning project, students plan problem-solving strategies, challenge ideas, monitor progress, test various solutions, and explain outcomes to each other. As students make sense of their experiences through testing, reflecting, modifying, and refining their thinking, knowledge is constructed.

\section{Criticisms of Service Learning}

Currently service learning is gaining popularity in higher education, but there are some who do not agree with the practice (Mattson, 1998). These critics contend that the service component waters down the curriculum, further weakening the quality of higher education, and that the time students spend volunteering in community agencies as part of a course might be better spent in the library or laboratory (Gray, Ondaatje, \& Zakaras, 1999). To address this concern, Battistoni (2002) emphasizes the importance of selecting placements intentionally to meet the learning objectives of the course. The organization benefiting from the service should be considered a partner in education providing structured opportunities for students to critically reflect on the civic nature of their experience. 
Manchester and Baiocchi (2001) question if service learning can do more harm than good when the motive to serve may supersede the needs as defined by the community being served. In other words, what is more important - the instruction or the service? Is it really possible to meet both the intended learning objectives and the community's needs? Howard (1998) argues that it is essential to create opportunities that are relevant and meaningful to both the community and the students. The purposeful planning, design, and implementation of activities around specific learning objectives should be done in collaboration with the community benefiting from the service to avoid conflicts between instructional and service objectives.

\section{Benefits of Service Learning; Strategies for Implementation}

Research indicates that well-implemented service learning programs support the long-term development of civic responsibility, while the impact of the activities address immediate intellectual and social benefits for students and the communities they serve (Billig \& Furco, 2002; MendelReyes, 1998). Roehlkepartain (2007), however, cautioned that positive outcomes are not automatic and will vary depending on the focus, scope and quality of the learning experience. $\mathrm{He}$ identified specific benefits for each stakeholder (students, campus, and community) to use as a benchmark for success, including:

- Service-learning gives an intentional strategy for addressing goals for learning and personal development through civic engagement and community service.

- Service-learning cultivates connections between the organization, schools, higher education, and other community groups.

- Service-learning increases program staff and volunteers' level of engagement, leadership capacity, and satisfaction with their work.

- Service-learning reinforces effective development practices, providing appropriate structure, supportive relationships, opportunities to belong, positive social norms, opportunities for skill building; and integration of school and community efforts.

In order to build an effective program that can attain benefits for each stakeholder, there must be: (1) teacher commitment; (2) a mutually beneficial partnership between the school and the community agency; (3) institutional commitment. The collaborative relationships fostered in this learning environment should be maintained through formal agreements and memorandums of understanding that clearly articulate the roles and responsibilities for each partner. Abregana (2006) suggested four different models for addressing these roles and implementing a service learning curriculum: (1) as part of a course, (2) as a specially designed course, (3) as a departmental program, or (4) as a departmental program in collaboration with partner agencies.

\section{IS 2002 Model Curriculum and Gudielines}

The IS 2002 Model Curriculum and Guidelines evolved from the IS 1997 Model Curriculum am and Guidelines. While the curricular content had been updated and aligned with social, business and academic change since the original model curriculum was released in 1997, four primary characteristics have remained central. The guidelines state:

Several characteristics of the IS profession have been relatively constant over time and have been integrated into the curriculum. These are:

1. IS professionals must have a broad business and real world perspective.

2. IS professionals must have strong analytical and critical thinking skills.

3. IS professionals must have interpersonal communication and team skills and have strong ethical principles. 
4. IS professionals must design and implement information technology solutions that enhance organizational performance. [Gorgone, et al. 2002]

The focus of these four points is on meeting professional requirements. The curriculum is critical in meeting these requirements, and core of that curriculum is the IS Body of Knowledge.

The IS body of knowledge consists of the topics to be taught at some level of competency in an IS curriculum. The IS 2002 body of knowledge is a reorganization and extension of the IS'97 body of knowledge. The body of knowledge was derived from surveys of practitioners and academics and mapping of relevant topics from curricula for Computer Science and other computer related disciplines. The elements or topics in the IS body of knowledge form the lowest level building blocks for the curriculum. The elements, with desired competency levels, are grouped under learning units and learning units are grouped into courses. (Gorgone et al., 2002)

The presentation areas and courses of the Body of Information Systems Knowledge consist of three categories:

1) Information Technology,

2) Organizational and Management Concepts, and Theory, and

3) Development of Systems.

Body of Information Systems Knowledge can be detailed as follows:

1.0 Information Technology

1.1 Computer Architectures

1.2 Algorithms and Data Structures

1.3 Programming Languages

1.4 Operating Systems

1.5 Telecommunications

1.6 Database

1.7 Artificial Intelligence

\subsection{Organizational and Management Concepts}

2.1 General Organization Theory

2.2 Information Systems Management

2.3 Decision Theory

2.4 Organizational Behavior

2.7 Managing the Process of Change

2.8 Legal and Ethical Aspects of IS

2.9 Professionalism

2.10 Interpersonal Skills

\subsection{Theory and Development of Systems}

3.1 Systems and Information Concepts

3.2 Approaches to Systems Development

3.3 Systems Development Concepts and Methodologies

3.4 Systems Development Tools and Techniques

3.5 Application Planning

3.6 Risk Management

3.7 Project Management

3.8 Information and Business Analysis

3.9 Information Systems Design 
3.10 Systems Implementation and Testing Strategies

3.11 Systems Operation and Maintenance

3.12 Systems Development for Specific Types of Information Systems

(Gorgone et al., 2002)

Finally, the suggested courses that would typically contain the content included as part of the core body of IS knowledge (both at the fundamental and advanced level) are:

\section{P. Prerequisite}

IS 2002.P0 Personal Productivity with IS Technology

\section{A. Information Systems Fundamentals}

IS 2002.1 Fundamentals of Information Systems

IS 2002.2 Electronic Business Strategy, Architecture and Design

\section{B. Information Systems Theory and Practice}

IS 2002.3 Information Systems Theory and Practice

\section{Information Technology}

IS 2002.4 Information Technology Hardware and Software

IS 2002.5 Programming, Data, File and Object Structures

IS 2002.6 Networks and Telecommunications

\section{Information Systems Development}

IS 2002.7 Analysis and Logical Design

IS 2002.8 Physical Design and Implementation with DBMS

IS 2002.9 Physical Design and Implementation in Emerging Environments

\section{E. Information Systems Deployment and Management Processes}

IS 2002.10 Project Management and Practice

\section{ABET-CAC IS Curriculum Accreditation Criteria}

The ABET-CAC IS Program Criteria number five is curriculum. This particular program criteria is based on the IS model curricula currently available, including IS 2002. The program criteria were written to provide individual programmatic flexibility in the context of a professional standard. The ABET-CAC IS program criteria are as follows:

Students have course work or an equivalent educational experience that includes:

a. Information Systems: One year that includes:

1. coverage of the fundamentals of a modern programming language, data management, networking and data communications, systems analysis and design and the role of Information Systems in organizations. [IS]

2. advanced coursework that builds on the fundamental coursework to provide depth. [IS]

b. Information Systems Environment: One-half year of coursework that includes varied topics that provide background in an environment in which the information systems will be applied professionally. [IS]

c. Quantitative analysis or methods including statistics. [IS] (ABET, p. 8) 
Section 1 and $2 \mathrm{~b}$ specifically relate to subject matter that inherently is integrated with the professional environment. In each of the IS areas specified, there is amble opportunity to integrate practice with the theory. Practical experience typically comes through projects and assignments reflective of business needs (programming, database, project management, networking, etc,). Internships in a professional environment can also support the theory and application presented in the classroom. Service learning projects in the context of the courses and topic areas can very powerfully integrate theory, application, practical experience, and social/global/economic impact as the following case demonstrates.

\section{Service Learning Project- The IS Course Case Study}

\section{Motivation and Significance}

One project that provided substantial benefits for the students and a nonprofit organization, uses Abregana's model to implement a service learning curriculum "as part of a course" objective. For this case study, the students' service learning opportunities were gained, outside the classroom, by interviewing users and gaining an understanding of the requirements to improve process work flow. The overall goal was to integrate the requirements into the design, development and implementation of an information system solution in order to gain productivity improvements. Oftentimes in academic settings, students in technical programs do not get the chance to enhance their soft skills (e.g., communication, interviewing, and understanding group dynamics). This service learning project helped students to strengthen their soft with hard skills (e.g. programming and database development) while getting practical experience in applying the systems development lifecycle to practical information management problems (Schwalbe, 2007).

HSWP is a non-profit educational institution that has provided continuous service to Pittsburgh and the Western Pennsylvania region since 1879. HSWP operates the Senator John Heinz Pittsburgh Regional History Center (Heinz History Center), the largest history museum in Pennsylvania, which opened to the public in 1996 in downtown Pittsburgh.

Since August 2005, collaborative efforts between the Heinz History Center and the undergraduate Computer Information Systems (CIS) majors has resulted in the creation of a "volunteer applications development" group with students and faculty from the university. Each semester, through the guidance of Computer Information System faculty members, students provide information technology support services to the Heinz History Center on projects ranging from providing training classes in the use of MS Office 2007 or creating customized reporting and queries via MS Access 2007 against archived collection data. One specific collaborative effort was during the fall 2007 and spring 2008 semesters where three students developed a database application to help the Heinz History Center Library and Archive (L\&A) users track, manage and report over 1,000 films donated by the Westinghouse Electric Corporation as part of their capstone CSC490 and CSC492 Senior Project I and Senior Project II course requirements.

\section{Project Background}

The L\&A users were in need of an efficient method to track artifacts held in an extensive archival collection, available to the community and academic researchers. They needed a database management system to track the content and condition for the Westinghouse film collection. By improving tracking and reporting methods, film collection would be more accessible and available to L\&A users as well as those researching the Westinghouse Electric Corporation.

One primary objective of the project was to remove the unstructured workflow (where L\&A users had Excel spreadsheets and paper documents) to track the Westinghouse films and replace the workflow with a centralized database with report capabilities. Therefore, the objective for the 
project was to have students define and build a front-end application with a purpose to: 1) enter and maintain the film collection data and 2) provide standard query and customized report capabilities.

Outcomes gained from the project provided the students experience in building computer information systems, with respect to:

- exposure to the "social networking" side of analysis and design by understanding the interpersonal skills needed for interviewing, and

- experience in building technically based computer systems that are used in problem solving and decision making in the workplace.

While there is significant information systems literature (Schwalbe, 2007) on the high failure rate for information systems design projects due to the lack of user and system developer communication, this project helped to alleviate that problem by having the students participate in all levels of the systems development lifecycle (planning, analysis, design, development, and implementation) and by working closely with L\&A users.

\section{Description of Prior Workflow and Project Solution}

The Heinz History Center uses a computer based information system, BiblioMondo, which provides digital collections for library and museum consortiums. While considered a leading solution for tracking, it is primarily used for library collections such as book and paper-oriented documents. It does not meet the needs of L\&A users in tracking and managing physical devices such as clothing, household items and films and does not provide required donor data attributes. Noted museum researchers Gilliland-Swetland and Chandler noted techniques to make archive collections useful through products such as BiblioMondo, but the content is too generalized and does not include adequate information technology based solutions. For this project, students analyzed the retrieval and reporting needs of the L\&A users at the managerial level as the basis to define the data to store within a centralized, normalized database management system. Once an understanding of the data requirements were captured, the students concentrated on data entry forms for data entry and standard reporting and queries for output.

Table 1 captures at a summary level the accomplishments of the students through the systems development lifecycle. The table notes the work breakdown structure of activities, the timeline in the semester that the work was accomplished, and the overall outcomes and deliverables provided by the students. In essence, it captures the project management overview and final synopsis of the project.

Table 1. Systems Development Life Cycle:

\begin{tabular}{|l|l|l|l|}
\hline Phases & $\begin{array}{l}\text { Work } \\
\text { Breakdown }\end{array}$ & Timeline: & Outcomes \\
\hline $\begin{array}{l}\text { Phase I: Investi- } \\
\text { gation and } \\
\text { Analysis }\end{array}$ & $\begin{array}{l}\text { Reviewed the existing process to } \\
\text { maintain multiple Excel spread- } \\
\text { sheets and defined the reporting } \\
\text { problems associated with the current } \\
\text { process. }\end{array}$ & $\begin{array}{l}\text { September } \\
2007\end{array}$ & $\begin{array}{l}\text { Project Proposal Document } \\
\text { by students: Confirmed pro- } \\
\text { ject objectives and scope. }\end{array}$ \\
\hline $\begin{array}{l}\text { Phase II: User } \\
\text { requirements, } \\
\text { technical specs }\end{array}$ & $\begin{array}{l}\text { Defined the reporting needs of the } \\
\text { L\&A archivists and the technology } \\
\text { needed for the new system. }\end{array}$ & $\begin{array}{l}\text { November } \\
2007\end{array}$ & $\begin{array}{l}\text { User needs, technical spec } \\
\text { docs by students: received } \\
\text { archivists' and faculty ap- } \\
\text { proval. }\end{array}$ \\
\hline
\end{tabular}




\begin{tabular}{|l|l|l|l|}
\hline Phases & $\begin{array}{l}\text { Work } \\
\text { Breakdown }\end{array}$ & Timeline: & Outcomes \\
\hline $\begin{array}{l}\text { Phase III: Data- } \\
\text { base and applica- } \\
\text { tion development }\end{array}$ & $\begin{array}{l}\text { Built and constructed the database } \\
\text { and application solution. MS SQL } \\
\text { Server 2005 for the centralized data- } \\
\text { base, and either MS Access 2007 or } \\
\text { Visual Studio.Net for the front end } \\
\text { application to maintain data, gener- } \\
\text { ate reports. }\end{array}$ & $\begin{array}{l}\text { December } \\
\text { January } \\
2008\end{array}$ & $\begin{array}{l}\text { Students began migration of } \\
\text { individual databases into cen- } \\
\text { tralized solution. Students } \\
\text { developed summary and de- } \\
\text { tailed reports. Review and } \\
\text { approval on completed work. }\end{array}$ \\
\hline $\begin{array}{l}\text { Phase IV: User } \\
\text { testing and ac- } \\
\text { ceptance }\end{array}$ & $\begin{array}{l}\text { Created a system test plan for L\&A } \\
\text { archivists to review the screens and } \\
\text { reports to test for adequacy. This } \\
\text { phase is an iterative process where } \\
\text { versions of the system were re- } \\
\text { viewed to ensure that the solution } \\
\text { met the project scope and their busi- } \\
\text { ness needs. }\end{array}$ & $\begin{array}{l}\text { February } \\
2008-\end{array}$ & $\begin{array}{l}\text { March 2008 } \\
\text { andents installed database } \\
\text { Center. }\end{array}$ \\
\hline $\begin{array}{l}\text { Phase V: Imple- } \\
\text { mentation, Docu- } \\
\text { mentation }\end{array}$ & $\begin{array}{l}\text { Moved the solution into production, } \\
\text { for use in day-to-day operations by } \\
\text { the users. }\end{array}$ & $\begin{array}{l}\text { April 2008 } \\
\text { system with approval or dis- } \\
\text { approve on adequacy of sys- } \\
\text { tem. Change requests were } \\
\text { captured by the students as } \\
\text { enhancements. }\end{array}$ \\
\hline
\end{tabular}

In May 2008, the students provided training to the L\&A users on the usage of the Westinghouse film database application. Actual film attributes were keyed via the data entry forms, and initial reports and queries were generated. With an enthusiastic response from the users, it was agreed that the information system more than adequately met their requirements, and operational processes were implemented to use the system on a day-to-day basis for film tracking and reporting. Feedback from the students confirmed that the project had remarkable value in gaining actual field experience in developing computer based information systems. The opportunity to create a user accepted technical solution, while balancing analysis, critical thinking and interpersonal communication skills, was a major success for the students in this service learning endeavor.

\section{Service Learning at the University Level with the Student Engagement Transcript}

While service learning provides an added and important dimension to the education process for which most students admit to be life changing, there may be a difficulty in initially getting students involved. A small number of universities in recognizing this potential difficulty has taken on two different yet complementary approaches to enhance student involvement. One approach has been to directly include a service learning semester long project in required courses as this paper suggests. As an example, a systems analysis course - required for the IS majorincorporates a service learning project to establish needs and plans for a e-government initiative for a local community. Students attend council meetings, interview decision makers, users, as well as specialized meetings with community leaders to access the current situation, needs, and long term goals. Then as a class project the students design, develop, and implement a viable design that includes a strategy, a budget, and time table for implementation. The next group of students takes on the role of implementing the program. This approach actively involves students as both a course and academic program requirement. 
The second approach involves an institutional commitment to student involvement in the community as part of their educational experience. While all colleges and universities have established academic transcripts as a way to validate and verify academic experiences, one university in particular has yet another institutional transcript. This second transcript is the Student Engagement Transcript (SET). Beginning Fall 2009, as a graduation requirement, all students must have involvement in at least three activities that can be validated, documented, and eventually listed on the official university Student Engagement Transcript. The student activity can be chosen from five categories to fulfill the graduation requirement. The categories include:

- Arts, Culture and Creativity: Students with earned entries in this category completed activities deemed to be creative in nature. Examples include the production of creative work such as visual art, electronic and digital media, design work, poetry, musical compositions, etc.

- Leadership: Students with earned entries in this category interacted with a variety of people from culturally diverse backgrounds by participating in study abroad programs, international faculty-led trips, and cultural immersion experiences.

- Undergraduate Research: Students with earned entries in this category conducted undergraduate research that transcended traditional classroom assignments. Students may have presented their work at research conferences or seminars, published in an appropriate academic journal or periodical, etc.

- Professional Experience: Students with earned entries in this category participated in professional experiences such as internships, cooperative opportunities, practicums, or clinical.

- Special Recognition, Special Projects and Participation: Students with earned entries in this category accomplished one of the following: certificates, awards, innovative projects, and co-curricular activities such as athletic teams, campus organizations, or task forces for special university events and programs.

- Service: Students with earned entries in this category donated their time and talents in partnership with University-approved non-profit organizations or governments.

While the SET was not a requirement until Fall 2009, nearly $40 \%$ of students graduating in May 2008 voluntarily had requested participation with the SET. Of those students, most had used service in the form as service learning as one of their transcripted entries. The purpose of the SET is two-fold. One is to encourage student participation in the community as an important and life changing part of their education. The other purpose is to provide future employers with yet another dimension of the graduate they are considering to hire. SET demonstrates attributes that go beyond meeting the minimum academic requirements of an education. It also officially validates and verifies information they are very much interested in that is an indicator of leadership, social responsibility, and the ability to work well with others.

\section{Summary and Future Research}

This paper introduces faculty and researchers on integrating various service learning projects and their usage within technology-based courses into the ABET-CAC accredited curriculum based on the IS 2002 Model Curriculum. It addresses the body of information systems knowledge categories in the IS 2002 Model Curriculum and the ABET-CAC IS Curriculum Accreditation Criteria as a basis for evaluation to service learning projects. A service learning case study focused on the courses, programs, and institutional requirements offered by the one Computer Information Sys- 
tems program. A second example provides the student engagement dimension for students to attain service learning as part of their institutional transcript.

While these projects were well-received and where students actually developed an information systems solution to improve process efficiencies within organizations, there is a need to encourage even greater student participation to widen the experience of introducing service projects into technology courses as well as the need to research its effectiveness. Embedding service learning into core course of the curriculum and institutional commitment to student learning such as the Student Engagement Transcript may enhance both student numbers and commitment to service learning projects while at the same time address the requirements in the IS 2002 Model Curriculum and ABET-CAC IS Curriculum Accreditation Criteria. The authors of this paper recognize that these projects are examples of initial efforts to bring service learning projects to bear within their respective university. Thus, it is our intention to conduct a more comprehensive study that addresses the types of projects undertaken, the outcomes of these projects, and student performance in subsequent courses (courses taken after a service learning experience) and its impact to the IS 2002 Model Curriculum and ABET-CAC Accreditation. The future work will include feedback from the students, as well as the service organization, to provide a benchmark on the value-added results from the service learning initiative and its relationship to future courses that offer service projects in technology-based programs.

\section{References}

ABET, Inc. Computing Accreditation Commission. (2008). Criteria for accrediting computing programs: Effective for evaluations during the 2009-2010 accreditation cycle. Retrieved 30 Nov. 2009 from http://www.abet.org/Linked\%20Documents-PDATE/Criteria\%20and\%20PP/C001\%200910\%20CAC $\% 20$ Criteria\%2012-01-08.pdf

Abregana, B. (2006). Service learning as a new pedagogy in higher education. Surabaya:National Seminar on Service Learning.

Bandura, A. (1977). Social learning theory. New York: General Learning Press.

Battistoni, R. M. (2002). Civic engagement across the curriculum: A resource book for service-learning faculty in all disciplines. RI: Campus Compact.

BiblioMondo. (2008). A new generation of library technologies. ISACS Software. Retrieved 7 Dec. 2008 from http://www.bibliomondo.com

Billig, S., \& Furco, A. (2002). Service-learning through a multidisciplinary lens: Advances in servicelearning research. Greenwich, CT: Information Age.

Brown, A. L., Metz, K. E., \& Campione, J. C. (1996). Social interaction and individual understanding in a community of learners. The influence of Piaget and Vygotsky. In A. Tryphon \& J. Voneche (Eds.), Piaget-Vygotsky: The social genius of thought (pp. 145-170). New York: Psychology Press.

Brown, A. L., \& Palinscar, A. M. (1989). Guided, cooperative learning and individual knowledge acquisition. In L. B. Resnick (Ed.), Cognition and instruction: Issues and agendas (pp. 393-451). Hillsdale, NJ: Lawrence Erlbaum.

Carver, R.L. (1997). Theoretical underpinnings of service learning. Theory into Practice, 36(3), 143-149.

Delorenzo, G., Kohun, F.G., \& Mackin, A. (2009). Service learning integration using information system courses. Issues in Information Systems.

Giles, D. E., Jr., \& Eyler, J. (1994). Theoretical roots of service learning in John Dewey: Toward a theory of service learning. Michigan Journal of Community Service Learning, (Fall), 77-85.

Gilliland-Swetland, A. J., Chandler, R. L., \& White, L. (2003). MOAC II user evaluation: Making museum content useful. Proceedings of the 66th Annual Meeting of the American Society for Information \& Technology -- Humanizing Information Technology, Long Beach, California, October 20 - 23, 2003. 
Gorgone, J. T. et al. (2002). IS 2002 model curriculum and guidelines for undergraduate degree programs in information systems. Association for Computing Machinery (ACM), Association for Information Systems (AIS), Association of Information Technology Professionals (AITP).

Gray, M. J., Ondaatje, E. H., \& Zakaras, L. (1999). Combining service and learning in higher education. Summary report. Santa Monica, CA: Rand.

Howard, J.P.F. (1998). Academic service learning: A counternormative pedagogy. In R. A. Rhoads \& J. P. F. Howard (Eds.), Academic service learning: A pedagogy of action and reflection (pp. 21-29). San Francisco: Jossey-Bass Publishers.

Jonassen, D., \& Henning, P. (1999). Mental models: Knowledge in the head and knowledge in the world. Educational Technology, 39(3), 37-42.

Lesh, R. (2002). Research design in mathematics education: Focusing on design experiments. In L. English (Ed.), International handbook of research design in mathematics education (pp. 27-51). Mahwah, NJ: Lawrence Erlbaum.

Manchester, H., \& Baiocchi, L. (2001). Reflecting on Jonathan Kozol's challenge: Who really benefits from service learning? Currents: The Newsletter of Youth Service California, IX(3). Retrieved from http://www.energizeinc.com/art/vvser.html

Mattson, K. (1998). Can service-learning transform the modern university? A lesson from history. Michigan Journal of Community Service-Learning, 5(Fall), 108-113.

McPherson, K. (1996) Service-learning: Getting to the heart of school renewal. Vancouver, WA: School Improvement Project.

Mendel-Reyes, M. (1998). A pedagogy for citizenship: Service learning and democratic education. In R. A. Rhoads \& J. P. F. Howard (Eds.), Academic service learning: A pedagogy of action and reflection (pp. 31-38). San Francisco: Jossey-Bass Publishers.

Roehlkepartain, E.C. (2007). Benefits of community-based service-learning. Scotts Valley, CA: Learn and Serve America's National Service-Learning Clearinghouse. Retrieved from http://servicelearning.org/instant info/fact sheets/cb facts/benefits cbosl/index.php

Schwalbe, K. (2007). Information technology project management (5th ed.). Boston, MA: Course Technology.

Stanton, T.K., Giles, D. E., \& Cruz, N.I. (1999) Service-learning: A movement's pioneers reflect on its origins, practice, and future. San Francisco: Jossey Bass Publishers.

Sweeney, A. E., \& Paradis, J. A. (2004). Developing a laboratory model for the professional preparation of future science teachers: A situated cognition perspective. Research in Science Education, 34, 195-219.

Vygotsky, L. S. (1978). Mind in society. Cambridge, MA: Harvard Press.

Weigert, K.M. (1998). Academic service learning: Its meaning and relevance. In R. A. Rhoads \& J. P. F. Howard (Eds.), Academic service learning: A pedagogy of action and reflection (pp. 3-10). San Francisco: Jossey-Bass Publishers.

Wenger E., McDermott, R., \& Snyder, W. M. (2002). A guide to managing knowledge: Cultivating communities of practice. Cambridge, MA: Harvard University Press. 


\section{Biographies}

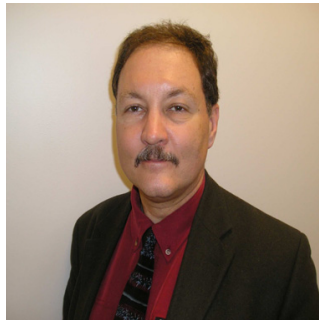

Frederick G. Kohun, Ph.D., Associate Provost and University Professor at Robert Morris University in Pittsburgh, Pennsylvania has more than 33 years experience as a professor, department head, and academic administrator in the information systems field. He holds a bachelor degree in economics from Georgetown University, graduate degrees in economics and information science, from the University of Pittsburgh, and a Ph.D. in applied history in technology from Carnegie Mellon University. At Robert Morris University he led the design and implementation of eight technology based academic programs at the undergraduate and graduate level (including a doctoral program) as well as the attainment of ABET-CAC accreditation. He is known both nationally and internationally from his numerous publications and presentations in health informatics, decision support, technological impact, and culture as well as his active involvement as an accreditation evaluator and team leader. In 2007 he was name Computer Educator of the Year by the International Association of Computer and Information Systems.

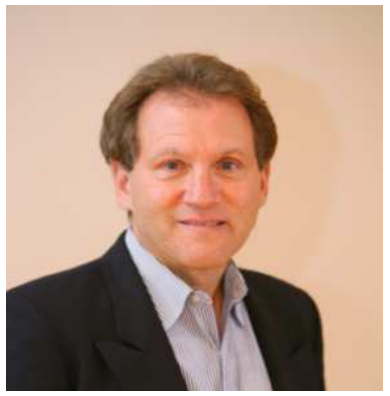

Gary J. DeLorenzo, D.Sc., Assistant Professor of Mathematics and Computer Science at California University of Pennsylvania in California, Pennsylvania has spent more than 30 years in industry as programmer, analyst, consultant and manager before entering academia. In his academic career, he has gained a reputation as someone who brings people together, shares his industrial experience with students, and brings his energy and knowledge for collaborative efforts. He has led initiatives at the university in areas such as marketing and recruitment to increase student enrollment, service learning projects for information system majors, and startup business incubation projects. He and his students provide ongoing data base consulting and application support services for the John Heinz History Museum, Pittsburgh, PA, the largest history museum in Pennsylvania. He was a visiting professor at Robert Morris University in 2004 and 2008, and has presented and published his research both nationally and internationally.

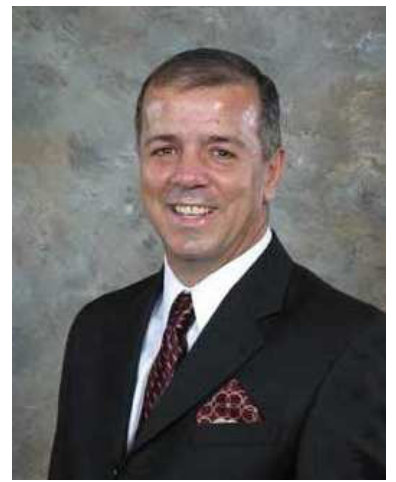

Azad Ali, D.Sc., Associate Professor of Technology Support and Training at Eberly College of Business - Indiana University of Pennsylvania has 23 years of combined experience in areas of financial and information systems. He holds a bachelor degree in Business Administration form the University of Baghdad, an M.B. A. from Indiana University of Pennsylvania, an M.P.A. from the University of Pittsburgh, and a Doctorate of Science in Communications and Information Systems form Robert Morris University. Dr. Ali's research interests include object oriented languages, web design tools, and curriculum design. His community service and academic expertise gets him in the news on Pittsburgh television and in the newspapers. 